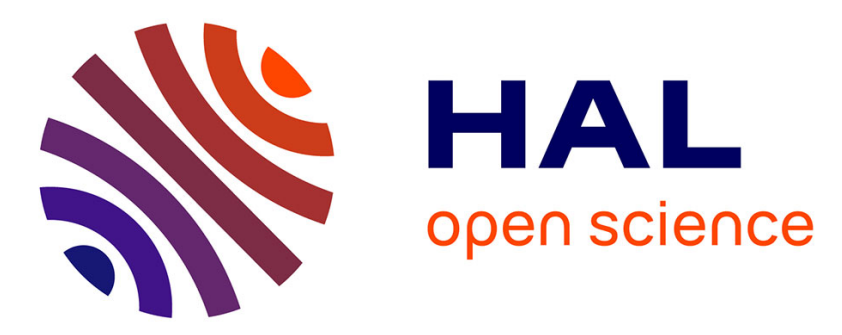

\title{
Non-invasive real time monitoring of cellular modifications with microwave dielectric spectroscopy at the single cell level
}

\author{
Katia Grenier, W. Chen, David Dubuc
}

\section{- To cite this version:}

Katia Grenier, W. Chen, David Dubuc. Non-invasive real time monitoring of cellular modifications with microwave dielectric spectroscopy at the single cell level. 2021 XXXIVth General Assembly and Scientific Symposium of the International Union of Radio Science (URSI GASS), Aug 2021, Rome, Italy. pp.1-3, 10.23919/URSIGASS51995.2021.9560506 . hal-03407670

HAL Id: hal-03407670

https://hal.laas.fr/hal-03407670

Submitted on 28 Oct 2021

HAL is a multi-disciplinary open access archive for the deposit and dissemination of scientific research documents, whether they are published or not. The documents may come from teaching and research institutions in France or abroad, or from public or private research centers.
L'archive ouverte pluridisciplinaire HAL, est destinée au dépôt et à la diffusion de documents scientifiques de niveau recherche, publiés ou non, émanant des établissements d'enseignement et de recherche français ou étrangers, des laboratoires publics ou privés. 


\title{
Non-invasive real time monitoring of cellular modifications with microwave dielectric spectroscopy at the single cell level
}

\author{
K. Grenier* (1), W. Chen ${ }^{(1)}$, and D. Dubuc ${ }^{(1)}$ \\ (1) LAAS-CNRS, Université de Toulouse, CNRS, UPS, Toulouse, France, https://www.laas.fr/public/en
}

\begin{abstract}
Microwave dielectric spectroscopy constitutes an attractive sensing technique for cellular analysis. One key feature is its ability to non-invasively and dielectrically monitor cellular modifications at the single cell level. The proposed microwave sensor dedicated to single cell measurement includes a mechanical trap, which permits to apply on individual cells whatever liquid-based environment. The dielectric consequences on the cell due to the application of saponine at $0.02 \%$ is recorded every two minutes, demonstrating the possibility to reach dielectric transformation kinetic of cells. This proof of concept opens the door to the non-invasive and nondestructive evaluation of biological reactions at the cellular level.
\end{abstract}

\section{Introduction}

Microwave dielectric spectroscopy is very attractive as it presents many advantages suitable for performing nondestructive and non-invasive sensing [1]. Solid, liquid or gaseous materials may be characterized by their dielectric properties, with a frequency-dependent response. The technique was firstly developed with large and cumbersome materials detection due to a lack of miniature equipment for various applicative domains such as the moisture sensing in agriculture, wood industry or food quality assessments $[2,3]$.

Since the advent of the microtechnologies and more recently microfluidic, it is possible to envision new applications for biology and medicine with molecular and cellular sensing notably. The intrinsic features of the microwave sensing naturally fulfil interesting abilities for cellular analyzes. It does not require any direct contact or labels. The microwave frequency range also gives access to internal modifications of cells as electromagnetic waves may bypass the bi-lipidic cytoplasmic membrane. Additionally, cells may be measured directly within their rich and salty traditional culture medium.

Firstly demonstrated with tissues, microwave spectroscopy was demonstrated for cell quantification, pathological state discrimination and even cell identification $[4,5]$, for cells suspensions and also at the single cell level $[6,7]$.

One attractive ability of the technique consists in monitoring the evolution of the material under test. This paper therefore focuses on the demonstration of monitoring the reaction of a cell to a chemical stress.

\section{Description of the microwave sensor dedicated to single cell measurements}

The microwave sensor includes a coplanar waveguide with two tapers and a capacitive gap located at its center. A photography is given in Fig. 1. This configuration permits to focalize the electromagnetic field, where the cell is placed for analysis.

Perpendicularly is crossing a microfluidic channel with a mechanical trap in its middle. This latter presents a small interstice below, in order to attract any cell arriving in front of it. Once a cell is trapped, the hydrodynamic flow rejects the other cells apart the blocker, leaving only one cell in the sensor for RF measurement. The main advantage of this trap is that it works regardless of the liquid used, whereas dielectrophoresis requires to fulfil specific rules between the dielectric properties of the element to trap compare to the host medium.

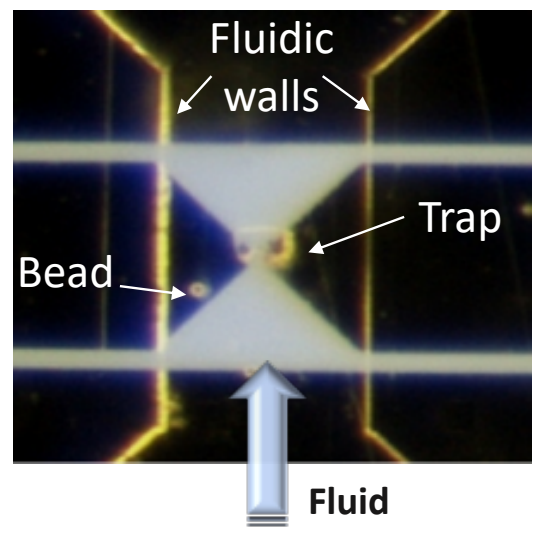

Figure 1. Photography of the microwave sensor dedicated to individual cell measurement, which includes a coplanar waveguide surmounted by a microfluidic channel with a cell trap. As an example, this photography includes a bead solution passing through the fluidic channel before trapping.

\section{Investigated cells and preparation protocol}


THP1 cell line is selected. These cells are derived from a human with an acute monocytic leukemia. They are grown in the RPMI culture medium. These circulating cells present a round shape.

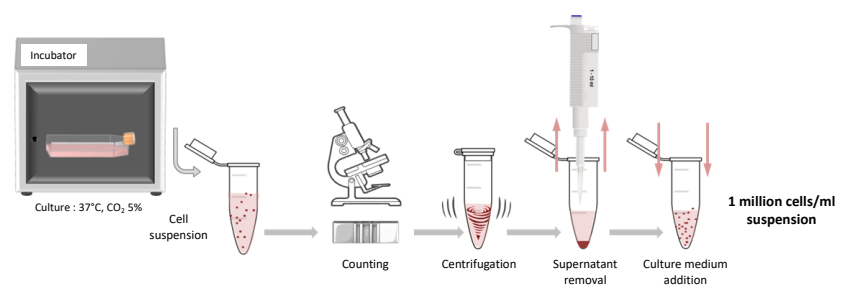

Figure 2. Protocol used to prepare the cell suspension samples.

For measurement, a cell suspension exhibiting a concentration of 1 million cells $/ \mathrm{ml}$ is prepared. Cells are removed from their culture plate with trypsine and placed in an Eppendorf. After counting, cells are centrifugated, allowing the replacement of the supernatant by a fresh culture medium, as indicated in Fig. 2.

To enable the monitoring of a short duration stress, a detergent, called saponine, is used. This chemical agent creates pores in the cytoplasmic membrane while maintaining the integrity of the rest of the cells. This chemical is used at $0.02 \%$ in combination to the culture medium.

\section{Evaluation of the time stability of cellular dielectric response}

Before monitoring a chemical stress, the stability of the test setup and the dielectric response of different models are evaluated. The sensor is consequently measured every 3 minutes for 15 minutes, while unloaded, followed by loaded with de-ionized water, RPMI culture medium, a polystyrene bead and finally a cell.

The capacitive response of the sensor is given in Fig. 3 for the different configurations.

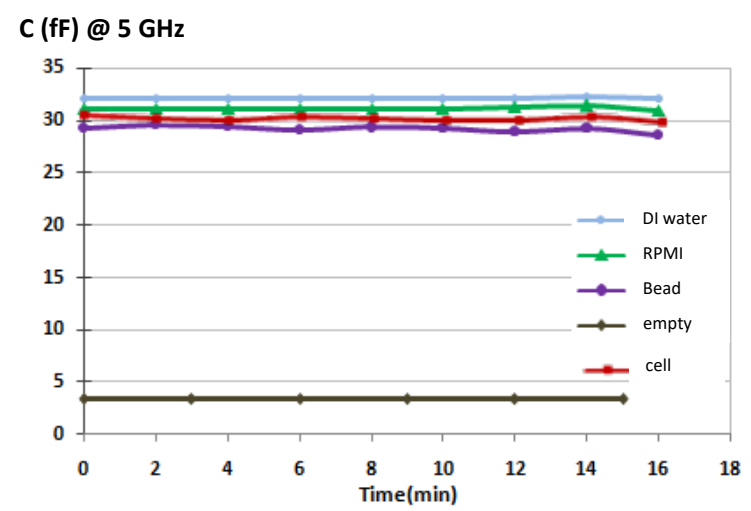

Figure 3. Time stability of the extracted capacitor of the sensor for different conditions : unloaded, loaded with DI water, with the RPMI culture medium, with one bead in culture medium and finally with a cell in culture medium.
The low measured standard deviations for each case enables the use of the sensor for monitoring cellular modification.

\section{Monitoring of a chemical stress on a single cell}

In a second step, a THP1 cell is trapped in the sensor. After 10 minutes, the culture medium is replaced by the saponine based one. Dielectric measurements are performed from $40 \mathrm{MHz}$ to $40 \mathrm{GHz}$, while the cell reaction is recorded for 10 additional minutes. As expected, the dielectric response of the cell changes, as visible on the fig. 4 . The capacitive contrast of the sensor loaded by the cell in liquid, compare to the sensor with only the culture medium starts to decrease in absolute value. The zero level on the ordinate axis corresponds to the culture medium employed as the reference level.

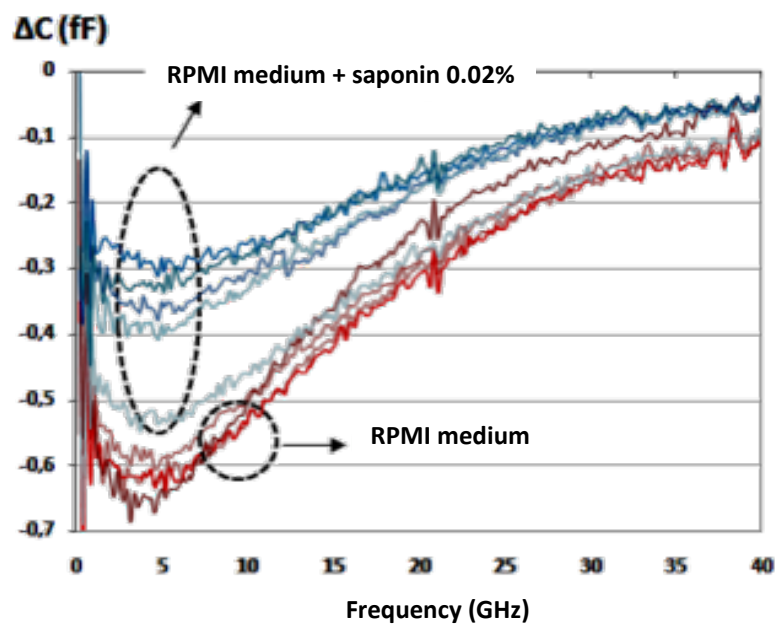

Figure 4. Monitoring of the capacitive contrast of a cell submitted to a chemical treatment.

As soon as the chemical is inserted in the vicinity of the cell, poration of the cell occurs, leading to its artificial and rapid death. This translates into the decrease of the capacitive contrast toward the reference level, as an exchange between the extra and intracellular liquids happens, progressively reaching an equilibrium between both compartments. The reference liquid level may not be reached as all organelles are still maintained within the cell.

To better highlight the cellular reaction, the dielectric kinetic is plotted at $5 \mathrm{GHz}$ in fig. 5. The cell exhibits a stable capacitive contrast, while maintained in its culture medium during the first 10 minutes. Once the chemical agent is added to the culture medium, the dielectric response of the cell is abrupt, reaching in only 4 minutes the smallest difference, compare to the culture medium followed by strong internal modifications. 


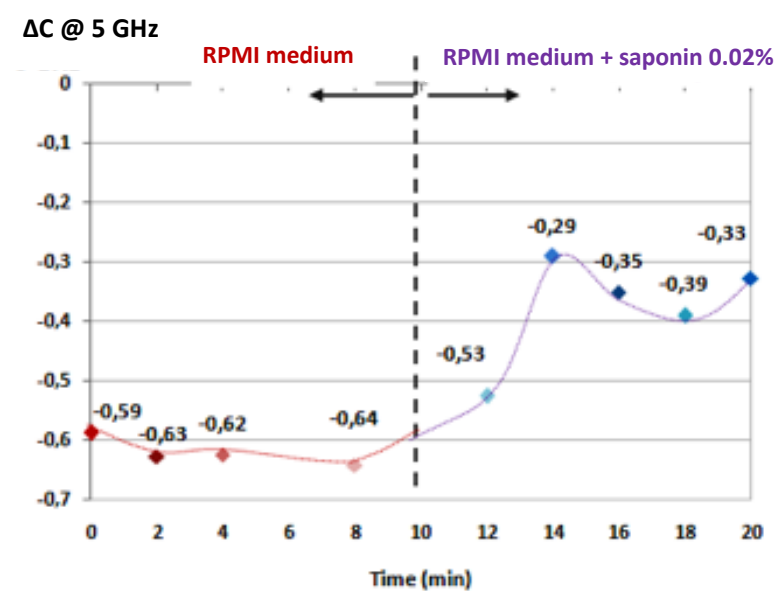

Figure 5. Evolution of the extracted capacitive contrast at $5 \mathrm{GHz}$ of an individual cell in its culture medium, submitted to a chemical treatment.

\section{Conclusions}

This paper deals with the possible monitoring of cellular modification with microwave dielectric spectroscopy. A microwave-based sensor suitable for the analysis of single cells is described. Its cell trapping mechanism based on a mechanical blocking with hydrodynamic flow enables to modify the host medium, whatever the dielectric properties of the liquids and the cells.

The proof of concept is obtained with the monitoring of a cancer cell submitted to a chemical agent, which creates rapidly holes in the cytoplasmic membrane. The dielectric response is recorded and reflects the cell modifications, leading to the death of the cell. In the proposed example, the time resolution is of 2 minutes. This value may be both increased or decreased depending of the targeted biological reactions to evaluate. Kinetic of biological processes may therefore be monitored, which may be of high interest in personalized medicine notably or to further understand both rapid or slow transformations of the living.

\section{Acknowledgements}

This work was partly supported by the LAAS-CNRS micro and nanotechnologies platform of the French RENATECH network.

\section{References}

1. K. Kupfer, "Electromagnetic aquametry," Springer, 2010.

2. S. Trabelsi et al., "New calibration technique for microwave moisture sensors," IEEE T-Inst. And Meas. $2001,50,4,877-881$

3. S. O. Nelson, W. Guo, S. Trabelsi, and S. J. Kays, "Sensing quality of watermelons through dielectric permittivity," Antennas and Propagation Society International Symposium, 2007 IEEE, 2007, pp. 285-288.

4. K. Grenier, D. Dubuc, T. Chen, F. Artis, T. Chretiennot, M. Poupot, J-J. Fournie, "Recent Advances in Microwave-based Dielectric Spectroscopy at the Cellular Level for Cancer Investigations," IEEE T-MTT, Vol. 61, Issue 5, Part 2, 2013, pp. 2023-2030.

5. K. Grenier, F. Artis, M. Poupot, J-J. Fournié, D. Dubuc, "Label-free discrimination of human lymphoma cell subpopulations with microwave dielectric spectroscopy," 2018 IEEE/MTT-S International Microwave Symposium Digest, June 10-15, 2018, DOI: 10.1109/MWSYM.2018.8439472.

6. X. Ma, X. Du, L. Li, H. Li, X. Cheng, J. Hwang, "Sensitivity Analysis for Ultra-wideband 2-port Impedance Spectroscopy of a Live Cell," IEEE Journal of Electromagnetics, RF and Microwaves in Medicine and Biology, June 2019, DOI: 10.1109/JERM.2019.2921221.

7. T. Chen, et al., "Microwave biosensor dedicated to the dielectric spectroscopy of a single alive biological cell in its culture medium," 2013 IEEE MTT-S International Microwave Symposium Digest, June 2-7, 2013, DOI: 10.1109/MWSYM.2013.6697740. 